\title{
Clinical and Anatomic Features of Acardiac Twins
}

\author{
Mohamed Bédis Chanoufia Riadh Ben Temimea Aïda Masmoudi ${ }^{\mathrm{b}}$ \\ Kamilia Ounaïssa ${ }^{a}$ Sami Jebnoun ${ }^{c}$ Walid Abid ${ }^{a}$ Rafika Nsiria Héla Chellia \\ Naïma Khroufc Soumaya Siala-Gaïgi ${ }^{b}$ \\ ${ }^{a}$ Department of Obstetrics and Gynecology, ${ }^{b}$ Fetal Pathology and ${ }^{c}$ Neonatology, Maternity and Neonatology \\ Center, Tunis, Tunisia
}

\section{Key Words \\ Acardius - Acephalus - Twin pregnancy · Twin reversed arterial perfusion sequence}

\begin{abstract}
Objective: To report 6 cases of acardiac twins, and to investigate prognostic factors that would lead to survival of the normal twin. Subjects and Methods: During a 9year period from 1993 to 2001, 6 cases of acardiac twins out of 109,000 deliveries at the Maternity Center, Tunis, Tunisia were studied. Detailed inspection, X-rays, ultrasound and autopsies were performed. Results: Prenatal diagnosis was made in only 1 case at 33 weeks of gestation. Rudimentary cardiac tissue was observed in 2 of the 6 perfused twins, and the cephalic pole was less developed than other parts of the body. Severe agenesis or hypoplasia of the thoracoabdominal organs was commonly observed. Many limb malformations were observed, with arms the most affected. One of the pump twins was stillborn, 3 died between days 1 and 3 from respiratory distress, and 2 developed cardiac failure after birth and were treated with diuretics and digoxin, which led to a favorable outcome in only 1 . The ratio of the
\end{abstract}

weight of the acardiac to pump twin (TWR) ranged from 50 to $142 \%$. Conclusion: The findings of this study indicate that acardia can be diagnosed by means of ultrasound in front of a monochorial twin pregnancy when one of the fetuses is deformed and has no cardiac activity. Heart failure and polyhydramnios, as well as a TWR greater than $50 \%$ are prognostic factors for the pump twin.

Copyright @ 2004 S. Karger AG, Basel

\section{Introduction}

Acardiac twinning is a rare malformation characterized by a usually normal 'pump' twin perfusing an anomalous 'perfused' or 'acardiac' recipient sibling via an arteryto-artery anastomosis, with reversed direction of flow of arterial blood to the perfused fetus. This hemodynamic reversal, known as 'twin reversed arterial perfusion', leads to a total or partial agenesis of the heart in the recipient twin, in addition to an absence of one or more anatomical structures [1, 2]. The survival and development of the acardiac fetus is strictly related to the presence of placental artery-to-artery anastomoses with the pump twin. Four

\section{KARGER \\ Fax +4161306 1234 \\ E-Mail karger@karger.ch \\ www.karger.com

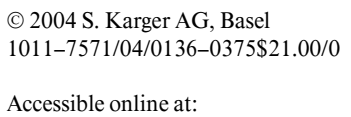

Chanoufi Mohamed Bédis

Department of Obstetrics and Gynecology

Maternity and Neonatology Center

21, rue Hamza Ibn Abdelmotaleb El Menzah 5, Tunis (Tunisia)

Tel. +21698320676, Fax +216 71238770, E-Mail badis.chanoufi@topnet.tn 
Table 1. Clinical and fetopathological features of acardiac twin

\begin{tabular}{|c|c|c|c|c|c|c|}
\hline & Case 1 & Case 2 & Case 3 & Case 4 & Case 5 & Case 6 \\
\hline Weight & $1,000 \mathrm{~g}$ & $300 \mathrm{~g}$ & $1,250 \mathrm{~g}$ & $1,150 \mathrm{~g}$ & $2,200 \mathrm{~g}$ & $2,300 \mathrm{~g}$ \\
\hline Sex & female & male & male & female & male & male \\
\hline Skin & $\begin{array}{l}\text { edema fat } \\
\text { panicle }\end{array}$ & $\begin{array}{l}\text { edema fat } \\
\text { panicle }\end{array}$ & $\begin{array}{l}\text { edema fat } \\
\text { panicle }\end{array}$ & $\begin{array}{l}\text { edema fat } \\
\text { panicle }\end{array}$ & $\begin{array}{l}\text { edema fat } \\
\text { panicle }\end{array}$ & $\begin{array}{l}\text { edema fat } \\
\text { panicle }\end{array}$ \\
\hline Cephalic pole & absent & facial buds & facial buds & exencephalia & hairy area & olfactory buds \\
\hline Upper limbs & absent & phocomelia & normal & phocomelia & absent & absent \\
\hline Lower limbs & $\begin{array}{l}\text { syndactyly } 3 \text { rd } \\
\text { toe agenesis }\end{array}$ & $\begin{array}{l}\text { bilateral } \\
\text { hypomelia }\end{array}$ & normal & normal & normal & $\begin{array}{l}4 \text { toes in each } \\
\text { foot }\end{array}$ \\
\hline Thoracic cage & dysplasia & dysplasia & normal & dysplasia & dysplasia & dysplasia \\
\hline Rudimentary cardiac tissue & absent & absent & present & present & absent & absent \\
\hline Liver & - & absent & absent & absent & - & absent \\
\hline Thyroid gland & - & - & present & - & - & absent \\
\hline Kidneys & polycystic & hypoplasia & agenesis & agenesis & - & hypoplasia \\
\hline GI tract & omphalocele & abnormal & undifferentiated & $\begin{array}{l}\text { esophageal } \\
\text { atresia }\end{array}$ & abnormal & $\begin{array}{l}\text { intestinal } \\
\text { atresia }\end{array}$ \\
\hline Classification & $\begin{array}{l}\text { holocardius } \\
\text { acephalus }\end{array}$ & $\begin{array}{l}\text { holocardius } \\
\text { anceps }\end{array}$ & $\begin{array}{l}\text { pseudoacardius } \\
\text { anceps }\end{array}$ & $\begin{array}{l}\text { pseudoacardius } \\
\text { anceps }\end{array}$ & $\begin{array}{l}\text { acardius } \\
\text { acephalus }\end{array}$ & $\begin{array}{l}\text { holocardius } \\
\text { acephalus }\end{array}$ \\
\hline
\end{tabular}

types of acardia are distinguished: acardius anceps (most similar in appearance to normal human beings); acardius acephalus (absence of head, with more or less developed trunk and limbs); acardius acormus (the head is the most developed element, whereas the trunk and limbs are reduced or absent), and acardius amorphus (an amorphous mass similar to a teratoma). Given that this bizarre anomalous acardiac fetus is sustained in utero by parasitic anastomoses to the circulation of its usually normal cotwin, the condition is not compatible with extrauterine survival. The aim of this report is to present the anatomical features of 6 cases of acardiac twins, report prognostic factors and outcomes, and highlight the need for improved prenatal diagnosis.

\section{Case Reports}

Six cases of acardiac twins out of 109,000 deliveries in the Maternity Center, Tunis, Tunisia were studied in the Fetopathology Laboratory during a 9-year period from January 1993 to December 2001. The maternal age ranged from 28 to 39 years, with a mean of 30.3 years. Antenatal ultrasound scans, detailed inspection, X-ray of the whole skeleton (cephalic pole, thoracic cage, upper and lower limbs, backbone) and autopsy of the fetus were performed. The surviving pump twins were observed.

Pregnancy occurred through normal spontaneous ovulation in 5 cases, while the other was through induction. One pregnancy had a complication of preeclampsia. Consanguinity was reported in 1 case. Anterior abortions were noted in 2 cases, and intrauterine death in 1 case. Antenatal ultrasound scans showed a monochorionic, diam- niotic twin pregnancy in 4 cases. The Doppler of the umbilical cord was abnormal in 2 cases: polyhydramnios in 1 case and pericardial effusion in the other. Although none of the recipient twins had cardiac activity, acardia was diagnosed antenatally in only 1 case at 33 weeks of gestation, having been suspected in the presence of an undifferentiated cephalic pole. In this case, the growth of the pump twin was very retarded, and no antenatal treatment was given. In the other cases, the antenatal diagnosis was acephalia in 2 cases and intrauterine death of 1 twin in 1 case. The delivery of the twins was vaginal in all 6 cases.

X-rays of the acardiac fetus showed mainly tiny cephalic buds, upper limb agenesis, phocomelia and rib hypoplasia. The morphological features of the acardiac fetuses are reported in table 1. Upon autopsy, all acardiac fetuses were found to be hydropic; they weighed from 300 to $2,300 \mathrm{~g}$. Three of the fetuses were classified as acardius anceps with a cephalic pole containing some primitive embryonic structures (fig. 1), while the other 3 fetuses were acardius acephalus (fig. 2) with no cephalic pole except a rudimentary hairy region in 2 cases. The cephalic pole was generally less developed than the other parts of the body. In addition, severe agenesis or hypoplasia of the thoracoabdominal organs was commonly observed. Rudimentary cardiac tissue was observed in 2 cases.

The kidneys were absent in 2 cases, polycystic in 1 and hypoplastic in the remaining 2 cases. Limb malformation was observed, with the arms the most affected. Two cases of phocomelia and 3 cases of amelia were identified. Backbone structures were present in all cases. Finally, the umbilical cord was thin and short in all cases.

As for the pump twins, their weights ranged from 600 to $2,150 \mathrm{~g}$. One pump twin was stillborn and 3 died between days 1 and 3 from respiratory distress. The remaining 2 pump twins developed cardiac failure, which was treated by diuretics $20 \mathrm{mg} /$ day and digoxin $0.75 \mathrm{mg} /$ day. The first twin died on day 7 from cardiac failure, respiratory distress and neonatal infection. The second twin was followed for 21 days under intensive care in the Department of Neonatology. 


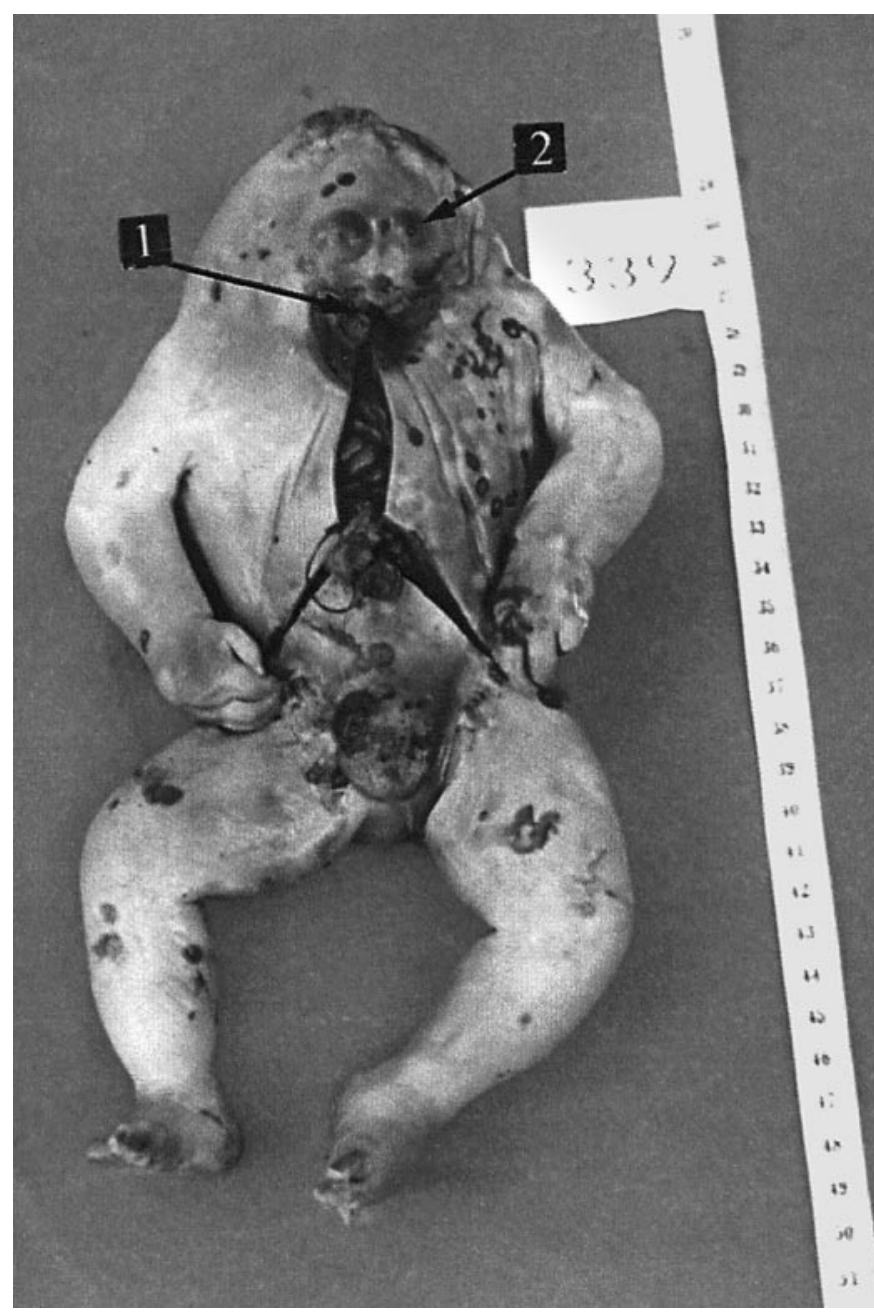

Fig. 1. Pseudoacardius anceps.

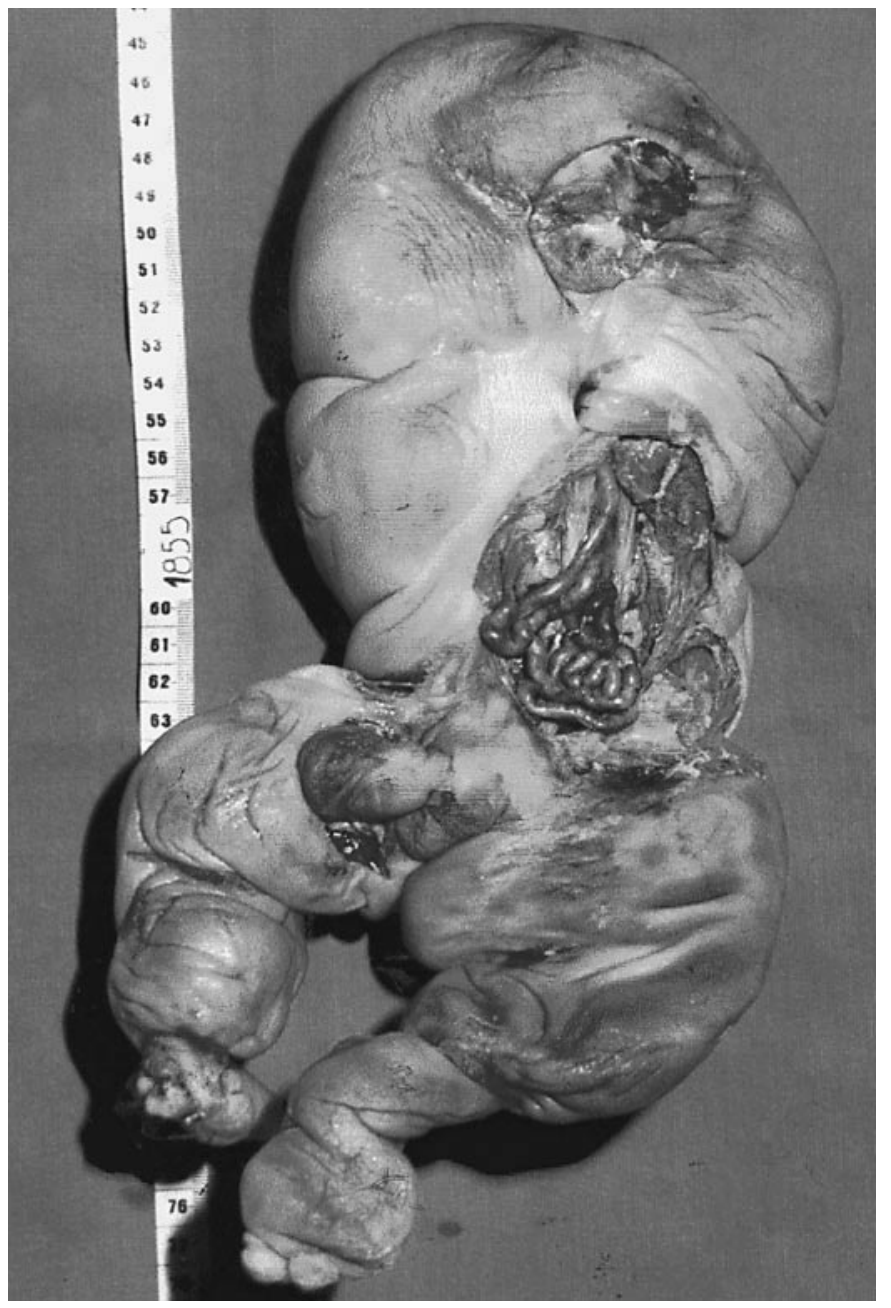

Fig. 2. Holoacardius acephalus.

Table 2. Acardiac/pump twin ratio

\begin{tabular}{|c|c|c|c|c|c|}
\hline & $\begin{array}{l}\text { Weeks of } \\
\text { gestation }\end{array}$ & $\begin{array}{l}\text { Weight of } \\
\text { acardiac twin }\end{array}$ & $\begin{array}{l}\text { Weight of } \\
\text { pump twin }\end{array}$ & TWR & $\begin{array}{l}\text { Outcome of } \\
\text { pump twin }\end{array}$ \\
\hline Case 1 & 30 & $1,000 \mathrm{~g}$ & $1,170 \mathrm{~g}$ & 0.93 & died day 1 \\
\hline Case 2 & 24 & $300 \mathrm{~g}$ & $600 \mathrm{~g}$ & 0.50 & died day 1 \\
\hline Case 3 & 41 & $1,250 \mathrm{~g}$ & $1,550 \mathrm{~g}$ & 0.80 & stillborn \\
\hline Case 4 & 31 & $1,150 \mathrm{~g}$ & - & - & died after 7 days 1 \\
\hline Case 5 & 32 & $2,200 \mathrm{~g}$ & $1,550 \mathrm{~g}$ & 1.42 & died after 3 days \\
\hline Case 6 & 33 & $2,300 \mathrm{~g}$ & $2,150 \mathrm{~g}$ & 1.07 & still alive $^{1}$ \\
\hline
\end{tabular}

1 Received cardiac treatment. 
The outcome was favorable. The twin is still alive and is being regularly followed. The twin weight ratio (acardiac/pump, TWR) ranged from 50 to $142 \%$; the outcome of the pump twin according to TWR at 1 week after birth is reported in table 2 .

\section{Discussion}

Acardiac acephalus is a rare occurrence resulting from extensive anastomoses between the vessels of monochorionic twins, which invariably leads to the death of the perfused twin and a high perinatal mortality rate in the pump twin, due mainly to premature delivery or congestive heart failure. The first cases of acardia were reported by Benedetti in 1533 and Benedictus in 1539, and later by Geoffroy in 1836. Five hundred cases have been reported since. The first classification of acardiac twins was presented by Das in 1902 and later modified by Napolitani $[1,3]$. The distinction criteria most widely accepted today are morphological; that is, the presence or absence of head, body and cardiac tissue. The frequency of acardia is estimated at $1 / 35,000$ deliveries [1,2], but in our study it occurred in $1 / 18,000$ deliveries.

The weights of the acardiac fetuses ranged from 300 to $2,300 \mathrm{~g}$ in our study, as compared to other studies that generally report weights of less than $1,000 \mathrm{~g}$, although some extremes have also been reported [1, 4-6]. Reports from the literature show that the frequency of acardius acephalus is greater than that of acardius anceps (68 and $8 \%$, respectively) [7], but in our series, there were 3 cases each of acardius acephalus and acardius anceps.

Profound disorganization of multiple organ systems in acardiac fetuses has been revealed by careful dissections since early reports of the condition [1, 6-8]. Rapidly growing structures such as the branchial arches, maxilla, and mandible are rudimentary because of the severe loss of blood flow in early development, but some acardiac acephalic fetuses do possess teeth. Many authors have reported pregnancy outcomes $[1,3,7,8]$, which seem to be influenced by the weight of the acardiac fetus compared to that of the pump fetus (TWR) [8]. When TWR exceeds $50 \%$, the prognosis of the normal fetus is worse. On the other hand, if the weight of the acardiac fetus is less than $25 \%$ compared to the pump fetus, the prognosis is better [8]. In our series, this ratio was greater than $50 \%$ in 5 cases. The one that survived had a TWR of $107 \%$. After a detailed analysis of 39 observations in the literature, we found that a TWR of $65 \%$ rather than $50 \%$ was more predictive of outcome, and we propose that this limit can be adapted to determine prognosis $[4,6,8]$.
The pump fetus is likely to develop cardiac failure in utero because of increased cardiac work to maintain its own circulation as well as that of the acardiac twin $[1,8]$. This cardiac failure results in a polyhydramnios and a high risk of prematurity. Moore et al. [8] reported that cardiac failure occurred in $53 \%$ of cases. The risk of cardiac failure is also related to the TWR: $25 \%$ of pump fetuses with a TWR greater than $50 \%$ will develop cardiac failure, whereas this risk is nearly zero if the TWR is less than $50 \%$. In this study 2 pump twins $(33 \%)$ had cardiac failure; however, the TWR of 5 ranged from 50 to $142 \%$. The ultrasound findings when cardiac failure occurs are atrial and ventricular enlargement, reverse Doppler flow over the tricuspid valve, hypokinetic ventricular movements and pericardial effusion [9]. In this study, pericardial effusion was reported in 1 case and polyhydramnios in 1 case. The umbilical cord Doppler was pathological in 2 cases but no specialized antenatal cardiac sonography was reported.

Many methods of management have been proposed. They include termination of pregnancy, serial ultrasound scans to monitor for signs of decompensation, medical management of polyhydramnios or management via serial amniocenteses, digitalization for prophylaxis or for treatment of cardiac failure, hysterotomy for removal of the anomalous twin, endoscopic clamping of the anomalous twin's cord, laser coagulation of the anastomosis and embolization of the circulation of the anomalous twin [913]. In our series, no antenatal therapy was performed. Attempted feticide of an anomalous acardiac twin by cardiac puncture represents a danger to the normal twin: any substance injected into the acardiac circulation could circulate to the normal twin.

Simpson et al. [10] successfully treated an acardiac pregnancy with digoxin after there were sonographic signs of cardiac insufficiency of the pump twin. Quintero et al. [11] reported successful ligation of the acardiac twin's umbilical cord with an endoscopic technique. Grab et al. [12] attempted fibrin occlusion of the umbilical vein of an acardiac fetus, but both fetuses died. Ginsberg et al. [13] achieved term delivery of a healthy pump twin after section delivery of the acardiac fetus in the second trimester.

Some complications resulting from these aggressive techniques are reported: premature delivery, risks of midtrimester hysterotomy with regard to future fertility, and survival of the normal twin as well as twin embolization syndrome, which damages the normal twin and can result in mental retardation [11-13]. 
Finally, the method of delivery is sometimes discussed because of the risk of dystocia in massively anomalous twins. Some cases of ruptured uterus have been reported $[1,8,9]$. In our series, the delivery was vaginal in all cases and no dystocia was observed. Umbilical Doppler can visualize the placental anastomoses as well as the reverse umbilical blood flow in the deformed fetus. A careful follow-up of the pregnancy is important in order to detect early cardiac failure and other complications.

\section{Conclusion}

The findings of this study indicate that acardia can be diagnosed by means of prenatal ultrasound in front of a monochorial twin pregnancy when one of the fetuses is deformed and has no cardiac activity. Heart failure and polyhydramnios as well as a TWR greater than $50 \%$ are prognostic factors for the pump twin.

\section{References}

1 Izquierdo L, Smith J, Gilson G: Twin, acardiac, acephalus. Fetus 1991;1:1-3.

-2 Stiller RJ, Romero R, Pace S, Hobbins J: Prenatal identification of twin reversed arterial perfusion syndrome in the first trimester. Am J Obstet Gynecol 1989;160:1194-1196.

>3 Benirschke K, Harper V: The acardiac anomaly. Teratology 1977;15:311-316.

4 Sherer DM, Armstrong B, Shah Y: Prenatal sonographic diagnosis, Doppler velocimetric umbilical cord studies, and subsequent management of an acardiac twin pregnancy. Obstet Gynecol 1989;74:472-475.

$\checkmark 5$ Chaliha C, Schwarzler P, Booker M, Battash MA, Ville Y: Case report: Trisomy 2 in an acardiac twin in a triplet in-vitro fertilization pregnancy. Hum Reprod 1999;14:1378-1380.
6 Fager C: Acardius in twins. J Gynecol Obstet Biol Reprod 1996;25:303.

7 Lachman R, McNabb M, Furmanski M, Karp L: The acardiac monster. Eur J Pediatr 1980; 134:195-200.

$>8$ Moore TR, Gale S, Benirschke K: Perinatal outcome of forty-nine pregnancies complicated by acardiac twinning. Am J Obstet Gynecol 1990;163:907-912.

9 Onnenfeld AE, Van de Woestijne J, Craparo F: The normal fetus of an acardiac twin pregnancy: Perinatal management based on echocardiographic and sonographic evaluation. Prenat Diagn 1991;11:235-244.
0 Simpson P, Trudinger B, Walker A, Baird P: The intrauterine treatment of fetal cardiac failure in a twin pregnancy with an acardiac, acephalic monster. Am J Obstet Gynecol 1983; 147:842-844.

11 Quintero RA, Reich H, Puder KS, Bardicef M, Evans MI, Cotton DB, Romero R: Brief report: Umbilical-cord ligation of an acardiac twin by fetoscopy at 19 weeks of gestation. N Engl J Med 1994;330:469-471.

12 Grab D, Schneider V, Keckstein J, Terinde R: Twin acardiac outcome. Fetus 1992;2:110 111.

13 Ginsberg NA, Applebaum M, Rabin SA: Term birth after midtrimester hysterotomy and selective delivery of an acardiac twin. Am J Obstet Gynecol 1992;167:33-37. 